\title{
MiR-133a-3p Relieves the Oxidative Stress Induced Trophoblast Cell Apoptosis Through the BACH1/Nrf2/HO-1 Signaling Pathway
}

\author{
Hui GUO ${ }^{1}$, Ying WANG ${ }^{2}$, Wenxin JIA ${ }^{1}$, Leilei LIU ${ }^{1}$ \\ ${ }^{1}$ Department of Obstetrics, The Fourth Hospital of Hebei Medical University, Shijiazhuang, Hebei, \\ People's Republic of China, ${ }^{2}$ Department of Gynecology, The Fourth Hospital of Hebei Medical \\ University, Shijiazhuang, Hebei, People's Republic of China
}

Received June 2, 2020

Accepted November 3, 2020

Epub Ahead of Print January 14, 2021

\section{Summary}

Preeclampsia (PE) is a major cause of the pregnancy morbidity and mortality over the world. Disorganized placentation caused by trophoblast cell abnormity is one of main risk factors to induce PE. MiR-133a-3p has been shown to contain regulatory effects on oxidative stress in the cardiomyocytes. But the effects of miR-133a-3p on oxidative stress-induced apoptosis in the trophoblast cells remain unknown. In this study, trophoblast HTR-8/SVneo cells were transfected with miR-133a-3p mimics and inhibitor. $\mathrm{H}_{2} \mathrm{O}_{2}(250 \mu \mathrm{M})$ treatment of cells was adopted to induce oxidative stress. A series of typical molecular and cellular experiments was subsequently performed in order to investigate this issue. It was found that miR-133a-3p overexpression attenuated the oxidative stress induced by $\mathrm{H}_{2} \mathrm{O}_{2}$ through reduced ROS and MDA levels and enhanced antioxidase activities in the trophoblast cells. Overexpressed miR-133a-3p was shown to relieve the oxidative stress-induced apoptosis of HTR-8/SVneo cells. At molecular levels, a direct binding effect of miR-133a-3p on $\mathrm{BACH} 1$ was verified. Moreover, miR-133a-3p overexpression also enhanced BACH1 downstream Nrf2/HO-1 signaling to activate antioxidant genes. It is collectively demonstrated that miR-133a-3p can relieve the oxidative stress-induced apoptosis in the trophoblast cells through the $\mathrm{BACH} 1 / \mathrm{Nrf2} / \mathrm{HO}-1$ signaling pathway via targeting $\mathrm{BACH} 1$ directly. This regulatory mechanism of miR-133a-3p in the trophoblast cells under oxidative stress may give a new perspective for oxidative stress-induced trophoblast cell abnormality and be useful to study more pathological mechanisms of $\mathrm{PE}$.

\section{Key words}

Trophoblast cells • Preeclampsia • Oxidative stress • microRNAs • Signal transduction

\section{Corresponding author}

H. Guo, Department of Obstetrics, The Fourth Hospital of Hebei Medical University, No. 12 Jiankang Road, Shijiazhuang, Hebei 050011, People's Republic of China. E-mail: guohui_sally@163.com

\section{Introduction}

One of the major causes of the maternal and perinatal death worldwide is preeclampsia (PE) that is commonly known as a pregnancy complication (Grotegut 2016). The incidence rate of $P E$ generally accounts for $3-5 \%$ of all pregnancies according to the publications (Mol et al. 2016). Besides, there is a great possibility of typical PE to occur during the period from twenty weeks after gestation to two days after delivery and the usual manifestations of it include hypertension and proteinuria (Sibai and Stella 2009). Currently, the pathological causes of PE for pregnant patients are still unclear, but several risk factors which may induce it have been well identified, such as nulliparity, family history, maternal age, multiple pregnancies, obesity, diabetes and also hypertension (Al-Jameil et al. 2014, Grotegut 2016). During gestation, normal deep placentation closely relies on the capacity of trophoblast cells to differentiate and invade (Straszewski-Chavez et al. 2005, Majali-Martinez et al. 2018). Dysregulation of trophoblast cell activities 
may also be one of the reasons to cause PE and it has already been reported that excessive apoptosis of trophoblast cells was highly related to the PE occurrence, which can be regarded as one of the pathogenesis of it (Straszewski-Chavez et al. 2005, Yu et al. 2012). Hence, the researches focusing on the trophoblast cells have gained more and more attention in the PE pathological studies.

MicroRNAs (miRNAs) are involved in the regulations of various cellular processes at both transcriptional and translational manners ( $\mathrm{Pu}$ et al. 2019). As a member of this huge small non-coding RNA family, miR-133a was studied a lot as a tumor suppressor in various cancer types (Ji et al. 2013, Uchida et al. 2013, Gong et al. 2015, Yang et al. 2017, Yin et al. 2019). It has been published that miR-133a promoted apoptosis in the bladder cancer (Uchida et al. 2013), esophageal cancer (Yang et al. 2017, Yin et al. 2019), gastric cancer (Gong et al. 2015) and osteosarcoma (Ji et al. 2013). But interestingly, miR-133a was shown to relieve the ischemia/reperfusion- or hypoxia-induced apoptosis in the cardiomyocytes to protect myocardium ( $\mathrm{Li}$ et al. 2015a, Li et al. 2015b, Ren et al. 2019, Yang et al. 2020), which also provided a potential therapy for cardiac disorders. Meanwhile, it was shown that overexpression of miR-133 increased superoxide dismutase (SOD) and glutathione peroxidase (GSH-Px) activities but reduce reactive oxygen species (ROS) and malondialdehyde (MDA) levels which are all the crucial indicators of oxidation in cardiomyocytes to protect cells from apoptosis induced by oxidative stress (Kumar et al. 2002, $\mathrm{Xu}$ et al. 2014), indicating that miR-133 may contain certain regulatory effects on oxidative stress in the cells.

Within a couple of years, miR-133a-3p has been found to maintain a higher expression level in the fetal umbilical cord blood circulation of PE pregnant patients (Hromadnikova et al. 2017). Besides, in the placental villous trophoblast samples of intra-amniotic infectioninduced preterm delivery, miR-133-3p showed an increased expression level versus that in the spontaneous preterm birth (Ackerman et al. 2016). As mentioned previously, since abnormity of trophoblast cell apoptosis may lead to PE emergence and miR-133a may regulate certain indicators to react to oxidative stress, the effects of miR-133a-3p on the oxidative stress-induced apoptosis in trophoblast cells have then attracted our interests. Here, we mainly aimed to investigate this issue and possible regulatory pathways involved in the regulations of miR-133a-3p, which may provide additional evidence to supplement the pathogenesis of PE and give a potential therapeutic perspective for PE treatment.

\section{Methods}

\section{Cell culture and treatment}

The human trophoblast cells HTR-8/SVneo were obtained from the Procell Life Science \& Technology Co., Ltd. (Wuhan, China). Cells were maintained in the RPMI-1640 medium (HyClone, Logan, Utah, USA) supplemented with $5 \%$ fetal bovine serum (FBS, Biological Industries, Kibbutz Beit-Haemek, Israel) and cultured in incubators at a constant temperature $37^{\circ} \mathrm{C}$ with $5 \% \mathrm{CO}_{2}$, as previously described (Yu et al. 2012). According to the experimental grouping, cells in relevant groups were treated with $250 \mu \mathrm{M} \mathrm{H}_{2} \mathrm{O}_{2}$ for $0,1,6,12$, or $24 \mathrm{~h}$ to induce oxidative stress and then adopted for further experiments.

\section{Cell transfection}

Cells were seeded on 6 -well-plates $\left(4 \times 10^{5}\right.$ per well) and cultured at $37{ }^{\circ} \mathrm{C}, 5 \% \mathrm{CO}_{2}$ for $24 \mathrm{~h}$. Then cells in each well were treated with $2 \mathrm{ml}$ serum-free medium for $1 \mathrm{~h}$ before transfection. In each well, $100 \mathrm{pmol}$ miR-133a-3p mimics or miR-133a-3p inhibitor or their NCs (JTS Scientific, Wuhan China) were transfected into HTR-8/SVneo cells using Lipofectamine ${ }^{\mathrm{TM}} 2000$ transfection reagent (Invitrogen, Thermo Fisher Scientific, Carlsbad, CA, USA) according to the manufacturer protocol. Besides, 50 pmol miR-133a-3p mimics and $1 \mu \mathrm{g}$ BACH1-overexpressed plasmid (SinoBiological, Beijing, China) were used for cell co-transfection. Further incubation of $250 \mu \mathrm{M} \mathrm{H}_{2} \mathrm{O}_{2}$ for $24 \mathrm{~h}$ was performed $24 \mathrm{~h}$ after transfection.

\section{Real-time PCR}

The high pure total RNA rapid extraction kit (BioTek, Beijing, China) was applied to extract total RNAs from samples. All procedures were based on the manufacturer protocol. The extracted RNAs were then reverse transcribed into cDNAs via M-MLV reverse transcriptase (Takara, Beijing, China) with RNase inhibitor (Takara) under conditions of: $25^{\circ} \mathrm{C}$ for $10 \mathrm{~min}$, $42{ }^{\circ} \mathrm{C}$ for $50 \mathrm{~min}$ and $80{ }^{\circ} \mathrm{C}$ for $10 \mathrm{~min}$ for following BTB and CNC homology 1 (BACH1, NM_001186.4) amplification (Oligo (dT) $)^{15}$ primer was used), and $37^{\circ} \mathrm{C}$ for $30 \mathrm{~min}, 42{ }^{\circ} \mathrm{C}$ for $30 \mathrm{~min}$ and $70{ }^{\circ} \mathrm{C}$ for $10 \mathrm{~min}$ for following miR-133a-3p amplification (Sequence of the 
RT primers of hsa-miR-133a-3p was: GTTGGCTCTGGTGCAGGGTCCGAGGTATTCGCACCAGAG CCAACCAGCTG). Followed real-time PCR reaction was performed using a total of $20 \mu \mathrm{l}$ mixture containing $1 \mu \mathrm{l}$ cDNA templates, $1 \mu \mathrm{l}$ primers $(10 \mu \mathrm{M}$, Genscript, Nanjing, China), $0.3 \mu \mathrm{l} \mathrm{SYBR}$ Green (BioTek) and $10 \mu \mathrm{l}$ $\mathrm{Taq}^{\mathrm{TM}}$ HS Perfect Mix (Takara) supplemented with $\mathrm{ddH}_{2} \mathrm{O}$. The reaction conditions of real-time PCR were 5 min at $94{ }^{\circ} \mathrm{C}, 40$ cycles of $20 \mathrm{~s}$ at $94{ }^{\circ} \mathrm{C}, 30 \mathrm{~s}$ at $60{ }^{\circ} \mathrm{C}$, and $40 \mathrm{~s}$ at $72{ }^{\circ} \mathrm{C}$ for subsequent $\mathrm{BACH} 1$ expression detection as well as $2 \mathrm{~min}$ at $94^{\circ} \mathrm{C}, 40$ cycles of $10 \mathrm{~s}$ at $94{ }^{\circ} \mathrm{C}, 15 \mathrm{~s}$ at $60^{\circ} \mathrm{C}$, and $15 \mathrm{~s}$ at $72^{\circ} \mathrm{C}$ for miR-133a-3p measurement. The relative expression levels of mRNA BACH1 and miR-133a-3p were calculated by $2{ }^{-\triangle \triangle} \mathrm{CT}$ method, with $\beta$-actin and U6 as internal references, respectively. Besides, specific primer sequences were shown as below: BACH1-F: AGAGCCCAGAACCAGGTCA, BACH1-R: TCAGAGTCGTCTCCCAAGC, $\beta$-actin-F: CTTAGTTGCGTTACACCCTTTCTTG, $\beta$-actin-R: CTGTCACCTTCACCGTTCCAGTTT, hsa-miR-133a-3p-F: GTTTGGTCCCCTTCAACC, hsa-miR-133a-3p-R: GCAGGGTCC-GAGGTATTC, U6-F: GCTTCGGCAGCACATATACT and U6-R: GTGCAGGGTCCGAGGTATTC.

\section{Indicator detection kits}

Several indicators involved in the oxidative stress were analyzed according to the manufacturer instructions from corresponding detection kits. MDA, total SOD (T-SOD) and GSH-Px assay kits (Nanjing Jiancheng Bioengineering Institute, China) were adopted to measure the MDA levels, SOD activities and GSH-Px activities within cells and BCA protein assay kit (Beyotime, Shanghai, China) was used to determine protein concentrations. Besides, enzyme activities of caspase-3 and caspase-9 were detected using the caspase-3 activity assay kit (Beyotime) and caspase-9 activity assay kit (Solarbio, Beijing, China) respectively, combined with the Bradford protein assay kit (Beyotime) detection for protein concentrations.

\section{Cell counting kit-8 (CCK-8) assay}

HTR-8/SVneo cells were seeded onto 96-wellplates $\left(3 \times 10^{3}\right.$ cells per well) for cell viability detection and each group contained five replicates. After $24 \mathrm{~h}$ of cell transfection and following $24 \mathrm{~h}$ of $\mathrm{H}_{2} \mathrm{O}_{2}(250 \mu \mathrm{M})$ incubation, each well was added $100 \mu$ l complete medium and $10 \mu \mathrm{l}$ CCK-8 reagents (Sigma-Aldrich, Darmstadt, Germany) for $1 \mathrm{~h}$ culturing at $37^{\circ} \mathrm{C}, 5 \% \mathrm{CO}_{2}$. Optical density values (OD) of cells were detected at $450 \mathrm{~nm}$ through a microplate reader (BIOTEK, Winooski, VT, USA).

\section{Flow cytometry}

The ROS assay kit (Keygen Biotech, Nanjing, China) was adopted to measure ROS levels of HTR-8/SVneo cells through a fluorescence probe DCFHDA according to the manufacturer protocol, which was then detected by flow cytometry (NovoCyte Flow Cytometers, Acea Biosciences, San Diego, CA, USA). For cell apoptosis analysis, Annexin V-FITC apoptosis detection kit (Beyotime) was used to double stain transfected cells through Annexin V-FITC and Propidium Iodide (PI) based on the manufacturer protocol, followed by fluorescence checking via NovoCyte Flow Cytometers. Besides, mitochondrial membrane potential assay kit with JC-1 (Solarbio) was applied, according to the manufacturer protocol, to observe the alterations of mitochondrial membrane potential using flow cytometry.

\section{Western blot (WB)}

Strong RIPA lysis buffer (Beyotime) was used to extract total proteins of samples and mitochondrial protein extraction kit (BOSTER, Wuhan, China) was applied to extract mitochondrial proteins from samples. All procedures were in accordance with corresponding manufacturer protocols. Protein quantification was performed through enhanced BCA protein assay kit (Beyotime) and then a certain amount of protein samples (15 $\mu \mathrm{l}, 15-30 \mu \mathrm{g})$ was loaded into gels to perform SDS-PAGE. Separated protein bands were then transformed onto PVDF membranes (Invitrogen, Carlsbad, CA, USA) through a "sandwich" structure. Prepared $5 \%$ (M/V) BSA (Biosharp, Hefei, China) was used to block membranes before incubation of membranes with primary antibodies at $4{ }^{\circ} \mathrm{C}$ overnight. After washing with TBST, membranes were incubated with secondary antibodies at $37^{\circ} \mathrm{C}$ for $40 \mathrm{~min}$. ECL chemiluminescence reagents (7-sea Biotech, Shanghai, China) were added on the membranes, followed by protein band scanning and analyzing through Gel-Pro-Analyzer software. Besides, specific information of primary antibodies was shown as below: Bcl-2 (1:500, Cat. No. 12789-1-AP, Proteintech, Wuhan, China), Bax (1:500, Cat. No. 50599-2-Ig, Proteintech), cytochrome C (1:1000, Cat. No. \#4272, Cell Signaling Technology, Danvers, MA, USA), BACH1 (1:500, Cat. No. A5393, Abclonal, Wuhan, China), nuclear factor-erythroid 
2-related factor2 (Nrf2, 1:500, Cat. No. 16396-1-AP, Proteintech) and Heme oxygenase-1 (HO-1, 1:1000, Cat. No. 27282-1-AP, Proteintech). Internal references were: COX IV (1:500, Cat. No. 11242-1-AP, Proteintech) for mitochondrial cytochrome C, Histone H3 (1:500, Cat. No. 17168-1-AP, Proteintech) for nucleus Nrf2, and $\beta$-actin (1:2000, Cat. No. 60008-1-Ig, Proteintech) for others. Secondary Goat Anti-Mouse IgG-HRP (1:10000, Cat. No. SA00001-1, Proteintech) was applied for $\beta$-actin and secondary Goat Anti-Rabbit IgG-HRP (1:10000, Cat. No. SA00001-2, Proteintech) was used for others.

\section{Dual luciferase reporter assay}

Dual luciferase assay was performed to detect the binding effects of miR-133a-3p on BACH1 in HTR-8/SVneo cells. Cells were seeded on 12-well-plates and carried out starvation treatment for $1 \mathrm{~h}$ when cell confluence was around $70 \%$ before transfection. Luciferase reporter vectors pmirGLO (Promega, Madison, Wisconsin, USA) containing wildtype (wt-BACH1: 5'-CCTTGAGAGTATATGGGGACCAGT-3') or mutant (mt-BACH1: 5'-CCTTGAGAGTATATGGCCTGGTGT-3') 3'UTR of BACH1 and miR-133a-3p mimics or NC mimics were co-transfected into cells using Lipofectamine $^{\mathrm{TM}} 2000$ transfection reagent (Invitrogen), followed by further luciferase activity detection through a Dual luciferase reporter assay kit (Promega) according to the manufacturer protocol.

\section{Statistical analysis}

All experiments were performed at least three times and the figures were showed as mean \pm standard deviation (SD). One-way ANOVA analysis in Graphpad Prism 8 (GraphPad Software, San Diego, CA, USA) was applied to analyze the differences between multiple groups, combined with the Turkey multiple comparison test. Besides, a statistically significant difference in this study was adopted as $P<0.05$.

\section{Results}

MiR-133a-3p alleviates the oxidative stress induced by $\mathrm{H}_{2} \mathrm{O}_{2}$ in HTR-8/SVneo cells

In order to investigate the alterations of miR-133a-3p and BACH1 in the trophoblast HTR-8/SVneo cells treated with $250 \mu \mathrm{M} \mathrm{H}_{2} \mathrm{O}_{2}$ for different time, real-time PCR was performed $0,1,6,12$, and $24 \mathrm{~h}$ after $\mathrm{H}_{2} \mathrm{O}_{2}$ incubation to evaluate relative mRNA levels of both miR-133a-3p and BACH1. It was shown that miR-133a-3p level was reduced significantly at $6 \mathrm{~h}$ after $\mathrm{H}_{2} \mathrm{O}_{2}$ treatment compared to cells without $\mathrm{H}_{2} \mathrm{O}_{2}$ treating, and the longer the $\mathrm{H}_{2} \mathrm{O}_{2}$ processing, the lower the miR-133a-3p would be (Fig. 1A). However, BACH1 expression showed apposite tendency, which was increased obviously after $\mathrm{H}_{2} \mathrm{O}_{2}$ treatment over time (Fig. 1A). To have a better understanding of miR-133a-3p regulation on $\mathrm{H}_{2} \mathrm{O}_{2}$-exposed trophoblast cells, HTR-8/SVneo cells were transfected with miR-133a-3p mimics and inhibitor then. The relative expression of miR-133a-3p was examined by real-time PCR after transfection, both of which showed significant transfection efficiency (Fig. 1B). Furthermore, to evaluate the redox state of $\mathrm{H}_{2} \mathrm{O}_{2}$-treated HTR-8/SVneo cells regulated by miR-133a-3p, cells were incubated with $250 \mu \mathrm{M} \mathrm{H} \mathrm{H}_{2} \mathrm{O}_{2}$ for $24 \mathrm{~h}$ after transfection for $24 \mathrm{~h}$. From the results, the MDA levels were remarkably increased and enzyme activities of antioxidases SOD and GSH-Px were reduced markedly in the $\mathrm{H}_{2} \mathrm{O}_{2}$-treated HTR-8/SVneo cells compared to the control, but those alterations caused by $\mathrm{H}_{2} \mathrm{O}_{2}$ were suppressed significantly by miR-133a-3p overexpression (Fig. 1C). Besides, the ROS levels were also measured, in which $\mathrm{H}_{2} \mathrm{O}_{2}$ incubation of trophoblast cells increased relative ROS level and further miR-133a-3p upregulation dropped off its level but miR-133a-3p downregulation enhanced it (Fig. 1D). Therefore, these findings demonstrate that $\mathrm{H}_{2} \mathrm{O}_{2}$ treatment for HTR-8/SVneo cells reduces miR-133a-3p levels but increases BACH1 expression. MiR-133a-3p overexpression reverses the enhanced MDA and ROS levels and decreased antioxidase activities induced by $\mathrm{H}_{2} \mathrm{O}_{2}$ in HTR-8/SVneo cells while miR-133a-3p knockdown shows opposite effects.

MiR-133a-3p relieves the apoptosis induced by oxidative stress in HTR-8/SVneo cells

To study how miR-133a-3p affects trophoblast cell apoptosis induced by oxidative stress, cell viability was firstly assessed after cell transfection. It was shown that $\mathrm{miR}-133 \mathrm{a}-3 \mathrm{p}$ overexpression restored the reduction of $\mathrm{H}_{2} \mathrm{O}_{2}$-induced cell viability in HTR-8/SVneo cells, but miR-133a-3p knockdown exacerbated this effect and led to lower cell viability compared to the $\mathrm{H}_{2} \mathrm{O}_{2}$-exposed cells (Fig. 2A). Besides, overexpression of miR-133a-3p also attenuated the increased apoptosis rate induced by $\mathrm{H}_{2} \mathrm{O}_{2}$ in the trophoblast cells but miR-133a-3p knockdown enhanced it (Fig. 2B). The activities of caspase-3 and caspase-9 in HTR-8/SVneo cells were evaluated by their detection kits, which showed that 

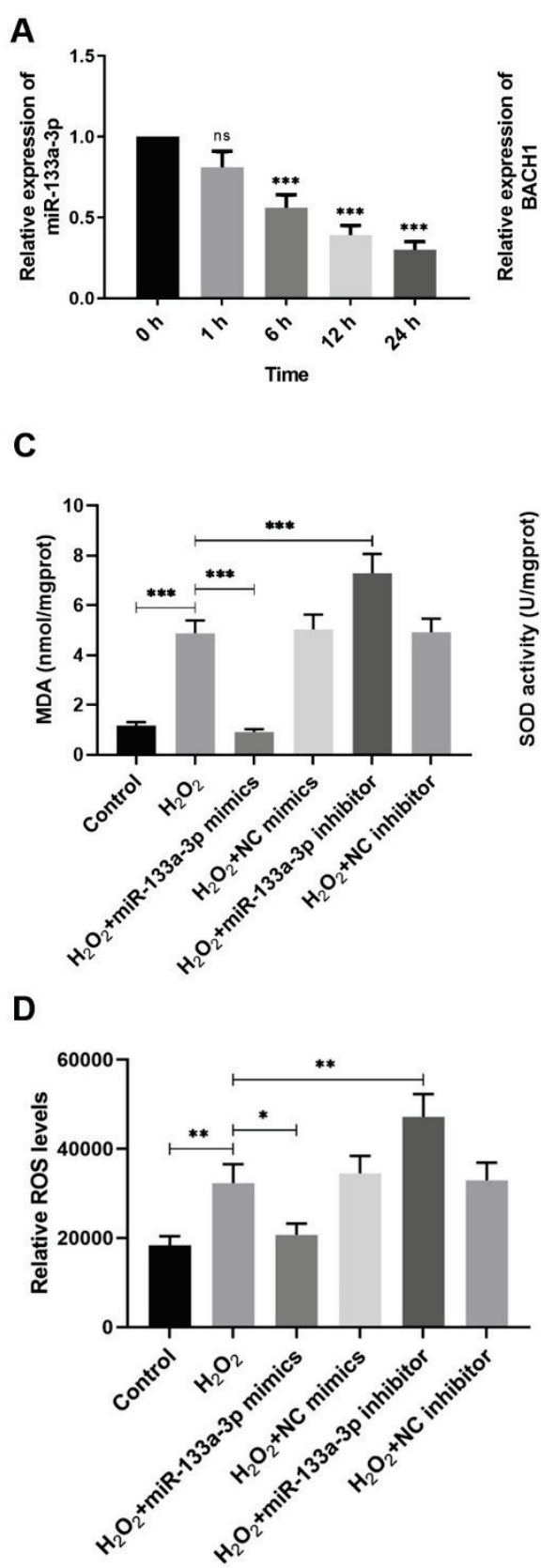
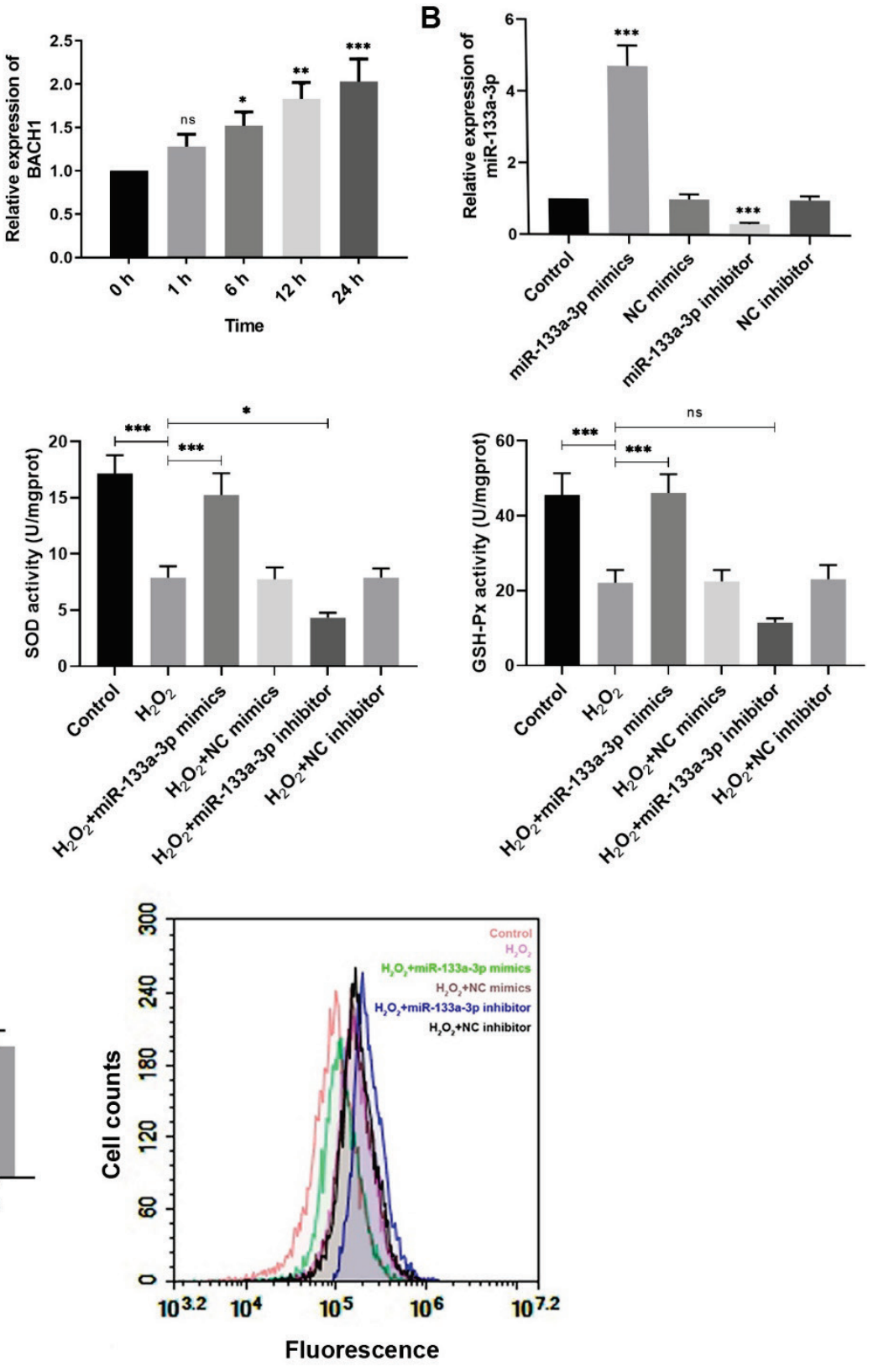

Fig. 1. MiR-133a-3p alleviates the oxidative stress induced by $\mathrm{H}_{2} \mathrm{O}_{2}$ in $\mathrm{HTR}-8 / \mathrm{SVneo}$ cells. (A) Real-time PCR was performed to evaluate the relative expression levels of miR-133a-3p and BACH1 in HTR-8/SVneo cells at $0,1,6,12$, and $24 \mathrm{~h}$ after $\mathrm{H}_{2} \mathrm{O}_{2}(250 \mu \mathrm{M})$ treatment. $* P<0.05$, ** $P<0.01, * * * P<0.001$, ns=no statistical significance versus the group with $\mathrm{H}_{2} \mathrm{O}_{2}$ treating for $0 \mathrm{~h}$. (B) Relative expression of miR-133a-3p in HTR-8/SVneo cells was measured after miR-133a-3p mimics and inhibitor transfection through real-time PCR. $* * * P<0.001$ compared with the control. (C) The MDA levels, SOD activities and GSH-Px activities were measured in $\mathrm{H}_{2} \mathrm{O}_{2}$-treated HTR-8/SVneo cells after transfection by corresponding detection kits. (D) The relative ROS levels were also determined through its detection kit via a fluorescence probe DCFH-DA. Flow cytometry was performed to analyze and quantify the fluorescence intensity in corresponding groups which represented their relative levels of ROS. $* P<0.05, * * P<0.01, * * * P<0.001$, ns $=$ no statistical significance. $\mathrm{H}_{2} \mathrm{O}_{2}$, hydrogen peroxide; $\mathrm{NC}$, negative control; $\mathrm{BACH} 1, \mathrm{BTB}$ and $\mathrm{CNC}$ homology 1; MDA, malondialdehyde; SOD, superoxide dismutase; GSH-Px, glutathione peroxidase; ROS, reactive oxygen species. One-way ANOVA combined with the Turkey multiple comparison test was used for data analysis.

miR-133a-3p overexpression alleviated the enhanced caspase activities induced by $\mathrm{H}_{2} \mathrm{O}_{2}$ (Fig. 2C). Moreover, WB was performed to detect protein levels of apoptosisrelated indicators under the same condition. The results showed that the $\mathrm{H}_{2} \mathrm{O}_{2}$-caused elevated levels of pro- apoptosis protein Bax and cytoplasmic cytochrome $\mathrm{C}$ were reduced after miR-133a-3p upregulation, but enhanced when miR-133a-3p was knocked down (Fig. 2D, E). Meanwhile, alterations of protein levels of anti-apoptosis $\mathrm{Bcl}-2$ and unreleased cytochrome $\mathrm{C}$ 
A

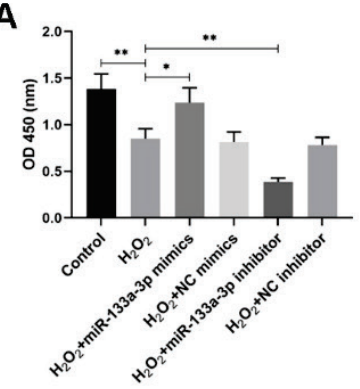

C

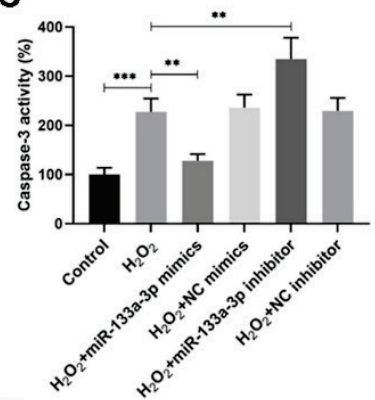

。

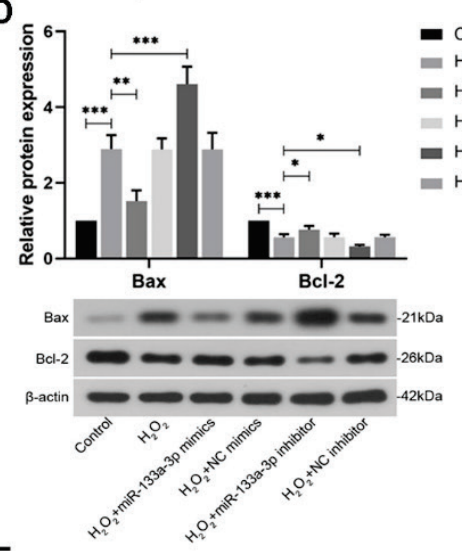

E

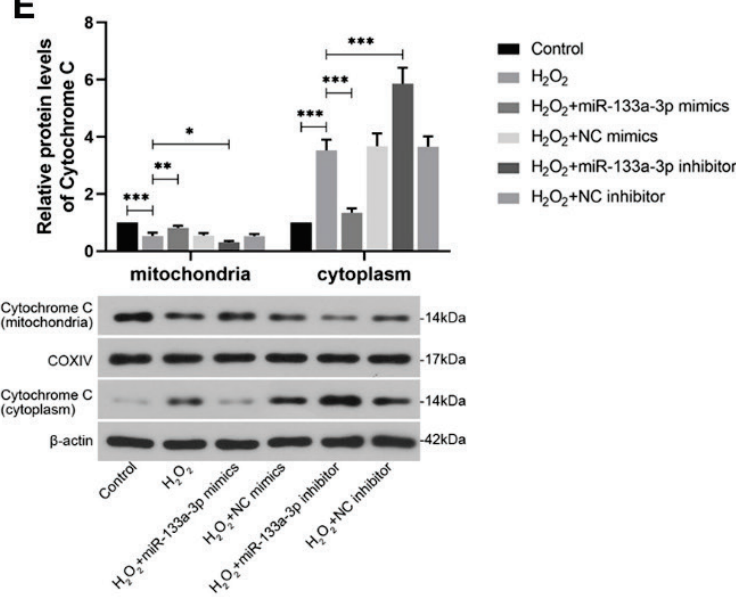

B
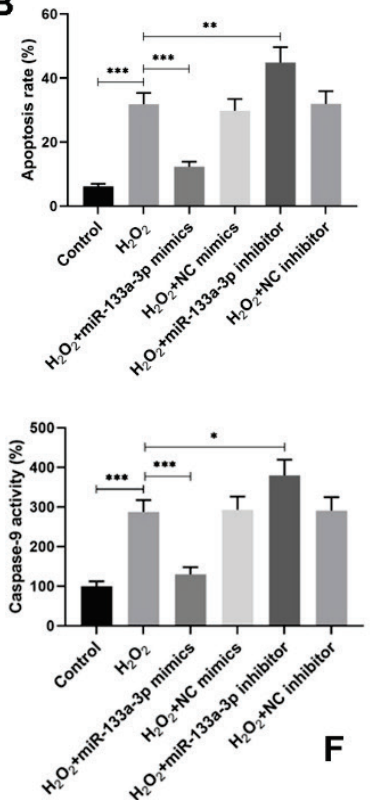

F

- Control

- $\mathrm{H}_{2} \mathrm{O}_{2}$

$\mathrm{H}_{2} \mathrm{O}_{2}+$ miR-133a-3p mimics

= $\mathrm{H}_{2} \mathrm{O}_{2}+\mathrm{NC}$ mimics

$\mathrm{H}_{2} \mathrm{O}_{2}+$ miR-133a-3p inhibitor

- $\mathrm{H}_{2} \mathrm{O}_{2}+\mathrm{NC}$ inhibitor
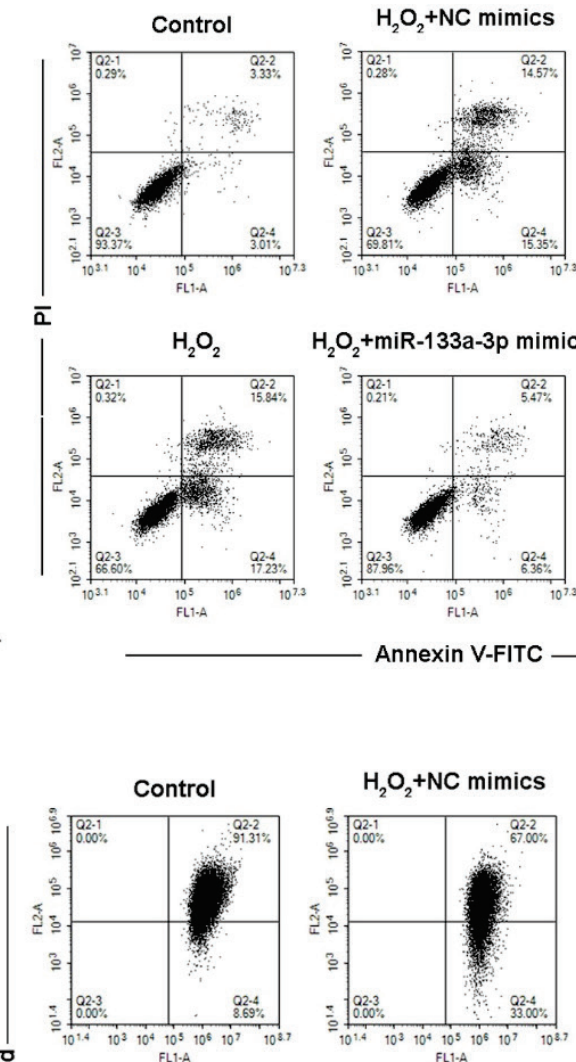

$\mathrm{H}_{2} \mathrm{O}_{2}+\mathrm{NC}$ inhibitor
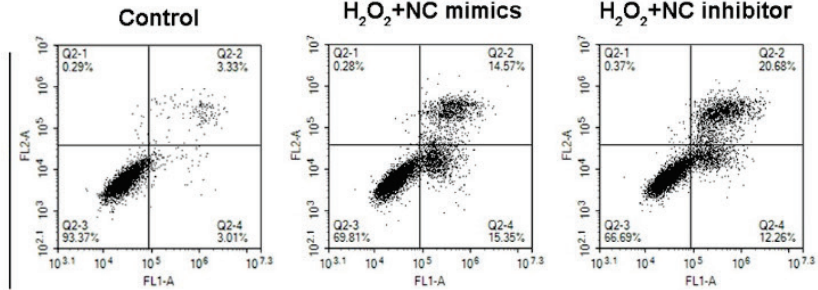

$\bar{\alpha}$

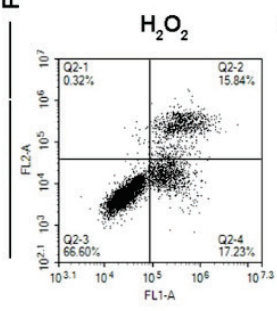

$\mathrm{H}_{2} \mathrm{O}_{2}+$ miR-133a-3p mimics $\mathrm{H}_{2} \mathrm{O}_{2}+m i R-133 a-3 p$ inhibitor
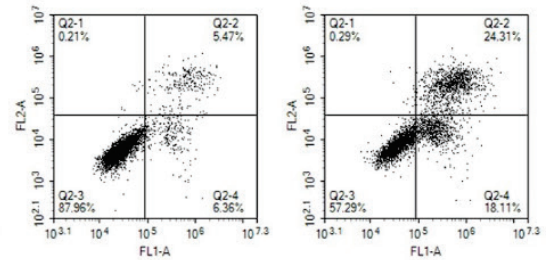

Annexin V-FITC

$\mathrm{H}_{2} \mathrm{O}_{2}+\mathrm{NC}$ mimics

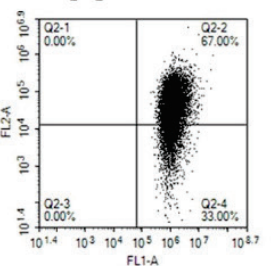

$\mathrm{H}_{2} \mathrm{O}_{2}+\mathrm{NC}$ inhibitor

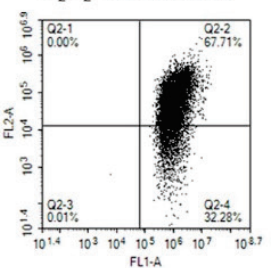

仓ั

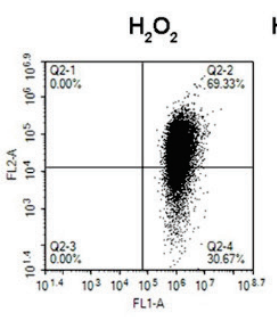

$\mathrm{H}_{2} \mathrm{O}_{2}+$ miR-133a-3p mimics $\mathrm{H}_{2} \mathrm{O}_{2}+$ miR-133a-3p inhibitor
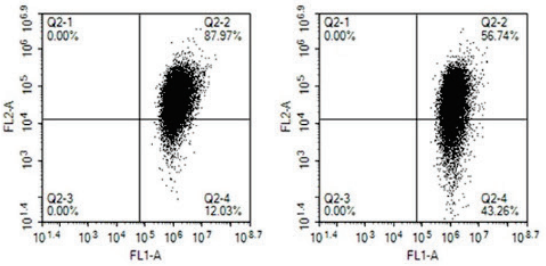

JC-1-green

$$
\begin{array}{lll}
\text { - Control } & \mathrm{H}_{2} \mathrm{O}_{2}+\text { miR-133a-3p mimics } & \mathrm{H}_{2} \mathrm{O}_{2}+\text { miR-133a-3p inhibitor } \\
\mathrm{H}_{2} \mathrm{O}_{2} & \mathrm{H}_{2} \mathrm{O}_{2}+\mathrm{NC} \text { mimics } & \mathrm{H}_{2} \mathrm{O}_{2}+\mathrm{NC} \text { inhibitor }
\end{array}
$$

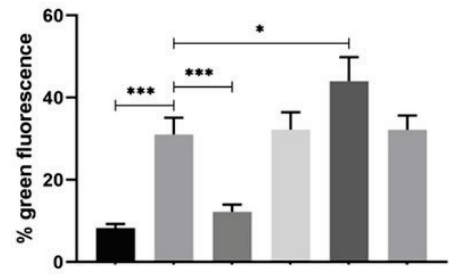

Fig. 2. MiR-133a-3p relieves the apoptosis induced by oxidative stress in HTR-8/SVneo cells. (A) CCK-8 assay was performed to detect cell viabilities in $\mathrm{H}_{2} \mathrm{O}_{2}(250 \mu \mathrm{M})$-treated $\mathrm{HTR}-8 / \mathrm{SVneo}$ cells after miR-133a-3p mimics or inhibitor transfection. (B) Flow cytometry was used to show and measure relative apoptosis rate of $\mathrm{H}_{2} \mathrm{O}_{2}$-exposed trophoblast cells after transfection through PI/Annexin V-FITC double staining. (C) Corresponding detection kits were adopted to measure the activities of caspase-3 and caspase-9 in HTR-8/SVneo cells exposed to $\mathrm{H}_{2} \mathrm{O}_{2}$ after miR-133a-3p mimics and inhibitor transfection. (D) WB assay was performed to detect relative protein expressions of pro-apoptotic protein Bax and anti-apoptotic protein Bcl-2 in $\mathrm{H}_{2} \mathrm{O}_{2}$-treated HTR-8/SVneo cells after transfection with their quantification. (E) WB images and their quantification of cytochrome $\mathrm{C}$ in the mitochondria and cytoplasm of $\mathrm{H}_{2} \mathrm{O}_{2}$-treated HTR-8/SVneo cells were showed. (F) Flow cytometry was applied to detect the alterations of mitochondrial membrane potential via JC-1 under same conditions. The green fluorescence emitted by JC-1 monomer was evaluated. $* P<0.05, * * P<0.01, * * * P<0.001$. $\mathrm{H}_{2} \mathrm{O}_{2}$, hydrogen peroxide; NC, negative control; PI, propidium; FITC, fluorescein isothiocyanate. One-way ANOVA combined with the Turkey multiple comparison test was used for data analysis. 
(mitochondria) were opposite in the $\mathrm{H}_{2} \mathrm{O}_{2}$-treated trophoblast cells after transfection (Fig. 2D, E). Furthermore, mitochondrial membrane potential in the cells was checked via a fluorescence probe JC-1. Since apoptotic cells would emit green fluorescence, it was found that miR-133a-3p overexpression significantly alleviated the $\mathrm{H}_{2} \mathrm{O}_{2}$-induced apoptotic cells but miR-133a-3p knockdown exacerbated cell apoptosis from oxidative stress (Fig. 2F). Hence, all these findings together suggest that miR-133a-3p can relieve the apoptosis induced by $\mathrm{H}_{2} \mathrm{O}_{2}$ in HTR-8/SVneo cells.

\section{MiR-133a-3p targets BACH1 directly}

To investigate certain related indicator involved in the miR-133a-3p regulations of trophoblast cell apoptosis induced by oxidative stress, a predicted target gene BACH1 of miR-133a-3p was studied. According to the online predicted binding sites of miR-133a-3p on 3'UTR of BACH1, dual luciferase reporter assay was performed to evaluate their target effects in HTR-8/SVneo cells. From the results, the cells co-transfected with wild type BACH1 3'UTR and miR-133a-3p mimics showed obviously lower luciferase activities compared to cells transfected with wild type BACH1 and $\mathrm{NC}$ mimics (Fig. 3), suggesting that
miR-133a-3p could bind to BACH1 directly.

MiR-133a-3p regulates $\mathrm{Nrf} 2 / \mathrm{HO}-1$ signaling circuit in $\mathrm{H}_{2} \mathrm{O}_{2}$-treated HTR-8/SVneo cells through BACH1

Thereafter, real-time PCR and WB were carried out to detect relative expression of BACH1 in $\mathrm{H}_{2} \mathrm{O}_{2}$-treated HTR-8/SVneo cells after transfection at mRNA and protein levels, respectively. It was shown that miR-133a-3p upregulation reduced the elevated BACH1 expression caused by $\mathrm{H}_{2} \mathrm{O}_{2}$ treatment at both transcriptional and translational levels, while miR-133a-3p knockdown enhanced their expression significantly (Fig. 4A, B). Moreover, using WB analysis, nucleus and cytoplasmic Nrf2 and its downstream effector HO-1 were analyzed, which showed that compared to the increased nucleus $\mathrm{Nrf} 2$ and reduced cytoplasmic Nrf2 after $\mathrm{H}_{2} \mathrm{O}_{2}$ treatment, overexpressed miR-133a-3p exacerbated these effects and led more Nrf2 into the nucleus and less Nrf2 into the cytoplasm, while miR-133a-3p knockdown would restore these alterations (Fig. 4C). Besides, although $\mathrm{H}_{2} \mathrm{O}_{2}$ treatment more or less unchanged the HO-1 protein levels in the cells, miR-133a-3p overexpression enhanced its levels remarkably and knockdown of miR-133a-3p reduced them (Fig. 4C).

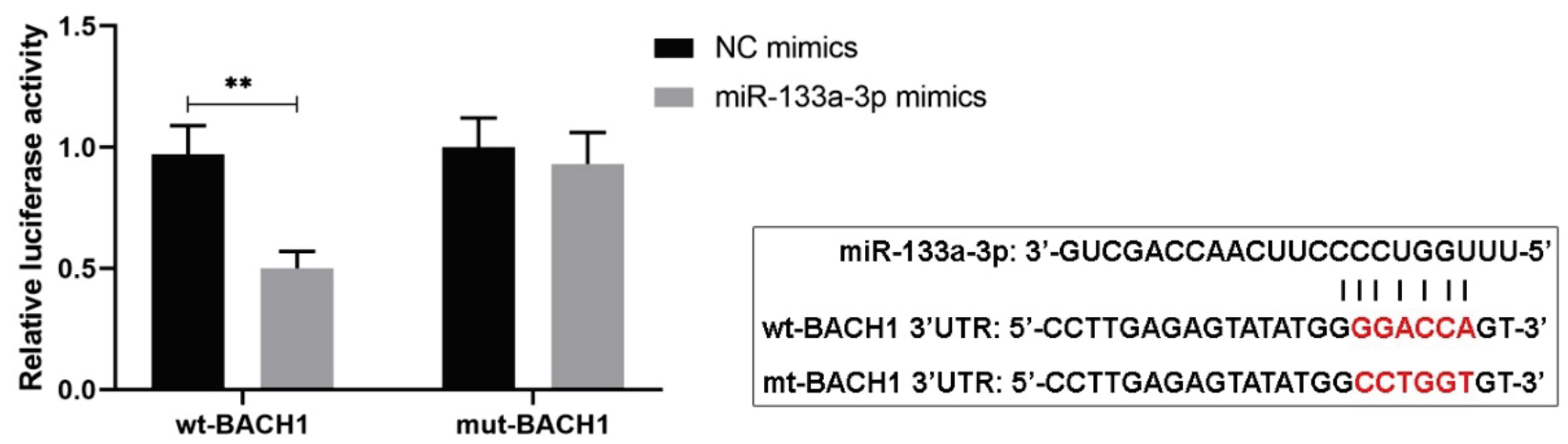

Fig. 3. MiR-133a-3p targets $B A C H 1$ directly. Dual luciferase reporter assay was performed to show the binding effects of miR-133a-3p on $3^{\prime} \mathrm{UTR}$ of BACH1 in HTR-8/SVneo cells. The predicted binding sequences of them and mutant sequence of BACH1 were also presented. $* * P<0.01$. NC, negative control; $\mathrm{BACH} 1, \mathrm{BTB}$ and $\mathrm{CNC}$ homology 1 ; wt, wild type; mt, mutant. One-way ANOVA combined with the Turkey multiple comparison test was used for data analysis.

Moreover, to study whether BACH1 participates in the regulation of miR-133a-3p on the $\mathrm{H}_{2} \mathrm{O}_{2}$-treated HTR-8/SVneo cell apoptosis and Nrf2/HO-1 signaling, the cells were co-transfected with the miR-133a-3p mimics and BACH1-overexpressing plasmid. The transfected efficiency of BACH1 overexpression in HTR8/SVneo cells was evaluated (Fig. 5A). It was shown that overexpressed BACH1 reversed the reduction of cell apoptosis rate and activities of caspase- 3 and 9 mediated by miR-133a-3p mimics under $\mathrm{H}_{2} \mathrm{O}_{2}$ treatment
(Fig. 5B, C). Besides, further upregulated BACH1 decreased the nucleus Nrf2 and further HO-1 expression level, which were enhanced by miR-133a-3p overexpression only in $\mathrm{H}_{2} \mathrm{O}_{2}$-treated HTR-8/SVneo cells (Fig. 5D). Since Nrf2/HO-1 signaling acts at the downstream of BACH1 to against oxidative stress, taken them together, it suggests that miR-133a-3p can regulate the HTR-8/SVneo cell apoptosis and also Nrf2/HO-1 signaling in response to oxidative stress induced by $\mathrm{H}_{2} \mathrm{O}_{2}$ through directly downregulating BACH1. 

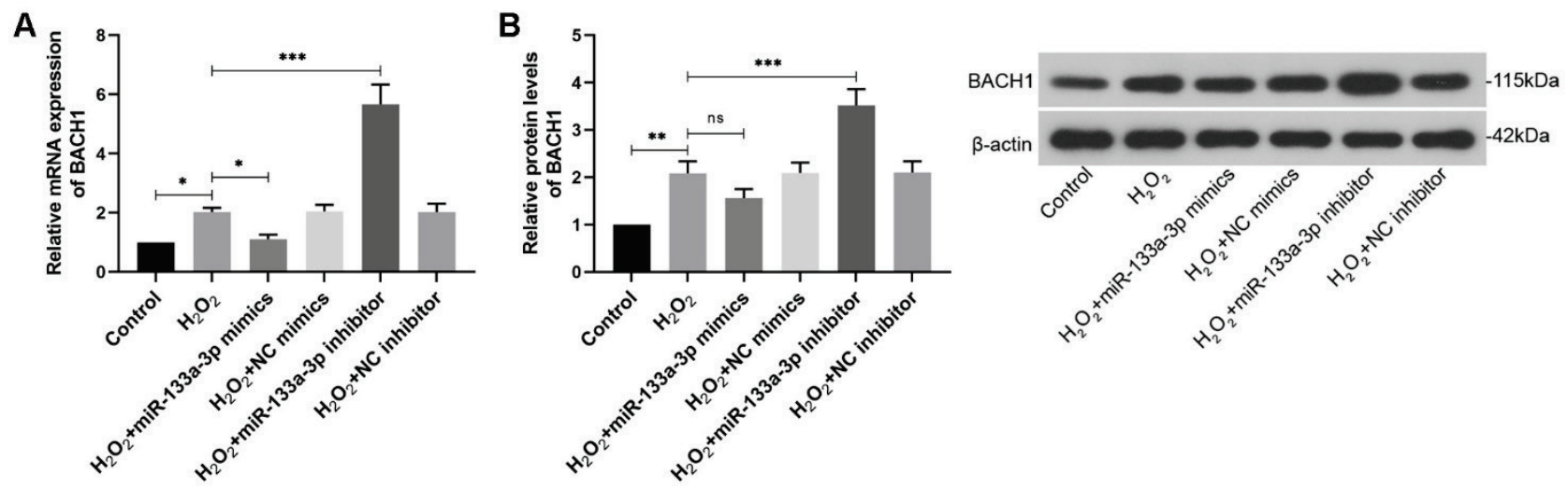

C
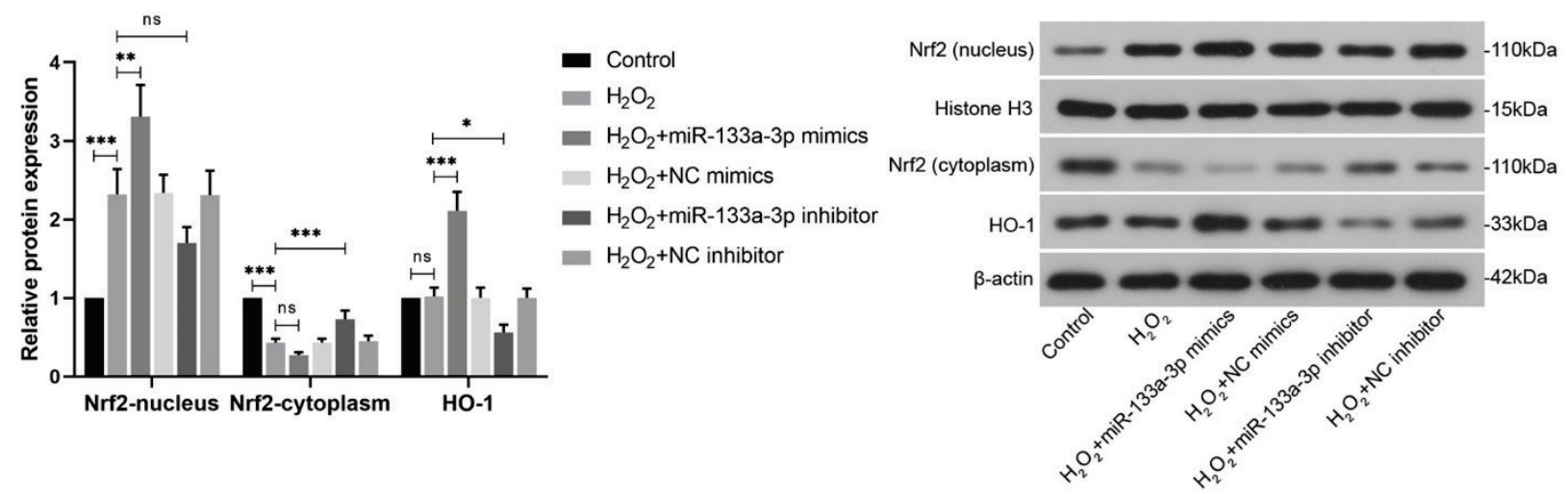

Fig. 4. MiR-133a-3p regulates $\mathrm{Nrf2} / \mathrm{HO}-1$ signaling circuit in the $\mathrm{H}_{2} \mathrm{O}_{2}$-treated $\mathrm{HTR}-8 / \mathrm{SVneo}$ cells. (A) Real-time PCR was performed to detect relative mRNA levels of $\mathrm{BACH} 1$ in $\mathrm{HTR}-8 / \mathrm{SVneo}$ cells exposed to $\mathrm{H}_{2} \mathrm{O}_{2}(250 \mu \mathrm{M})$ after miR-133a-3p mimics and inhibitor transfection. (B) WB was conducted to measure relative protein levels of BACH1 in $\mathrm{H}_{2} \mathrm{O}_{2}$-treated $\mathrm{HTR}-8 / \mathrm{SVneo}$ cells after transfection. (C) WB images and their quantification of nucleus Nrf2, cytoplasmic Nrf2 and $\mathrm{HO}-1$ proteins in the $\mathrm{H}_{2} \mathrm{O}_{2}$-exposed trophoblast cells after transfection were showed. $* P<0.05$, $* * P<0.01$, $* * * P<0.001$, ns=no statistical significance. $\mathrm{H}_{2} \mathrm{O}_{2}$, hydrogen peroxide; $\mathrm{NC}$, negative control; BACH1, BTB and CNC homology 1; Nrf2, nuclear factor-erythroid 2-related factor2; HO-1, heme oxygenase-1. One-way ANOVA combined with the Turkey multiple comparison test was used for data analysis.

\section{Discussion}

Although particular factors to cause PE are still not precisely understood, the occurrence of PE is related to various pathophysiological pathways, in which abnormal placental function has been known to play a crucial role to induce PE (Lv et al. 2019). As abnormal trophoblast cell activities are largely related to placental dysfunction (Straszewski-Chavez et al. 2005), the studies involving trophoblast cell apoptosis seem to be significant for PE treatment. Meanwhile, it has been wellexplored that the changes of several miRNAs in PE could regulate trophoblast function, mesenchymal stem cell effects and also angiogenesis (Lv et al. 2019). Here, our present study mainly investigated the regulation of miR-133a-3p on the trophoblast cell apoptosis induced by oxidative stress from $\mathrm{H}_{2} \mathrm{O}_{2}$, which may provide another potential target for PE-related therapy. Previous studies indicated that miR-133a-3p was downregulated in the $\mathrm{H}_{2} \mathrm{O}_{2}$-treated cardiomyocytes (Xu et al. 2014, Song et al.
2017). Combined with the antioxidative effects of miR-133a on the redox indicators in cardiomyocytes to respond to the oxidative stress induced by $\mathrm{H}_{2} \mathrm{O}_{2}(\mathrm{Xu}$ et al. 2014), the present results also showed similar regulation of miR-133a-3p on the redox indicators to against oxidative stress in trophoblast cells as evidenced by enhanced antioxidases, but attenuated ROS and MDA levels.

Because of the antioxidant effects of miR-133a$3 p$ under oxidative stress, overexpression of miR-133a-3p alleviated the increased apoptosis induced by $\mathrm{H}_{2} \mathrm{O}_{2}$ in trophoblast cells. Moreover, from the WB results of altered apoptotic indicators, it seemed that in HTR-8/SVneo cells, miR-133a-3p affected the intrinsic mitochondria-related apoptosis pathway to thereby regulate trophoblast cell apoptosis under oxidative stress. It is known that cytochrome $\mathrm{C}$ released from the mitochondria could induce apoptosis through activating downstream caspase-9 and subsequent caspase-3 activities ( $\mathrm{Li}$ et al. 1997). Combined present findings 

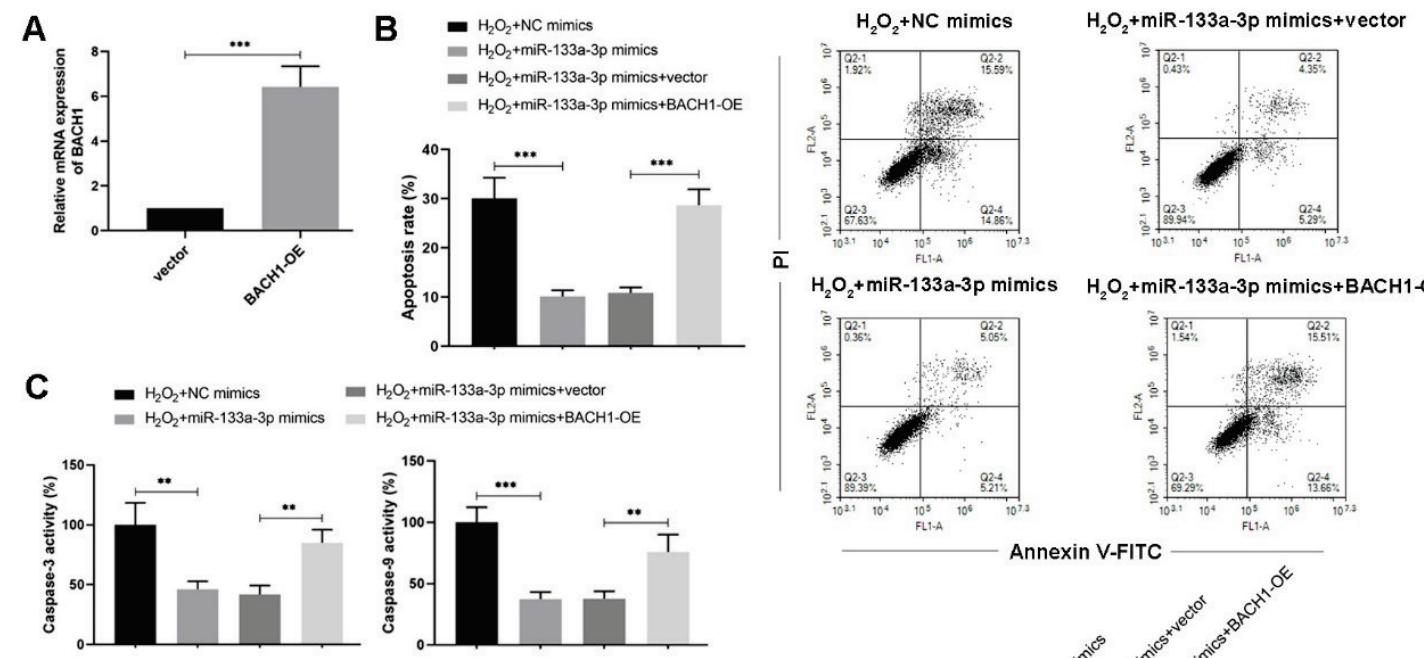

$\mathrm{H}_{2} \mathrm{O}_{2}+$ miR-133a-3p mimics+vector

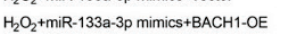

D
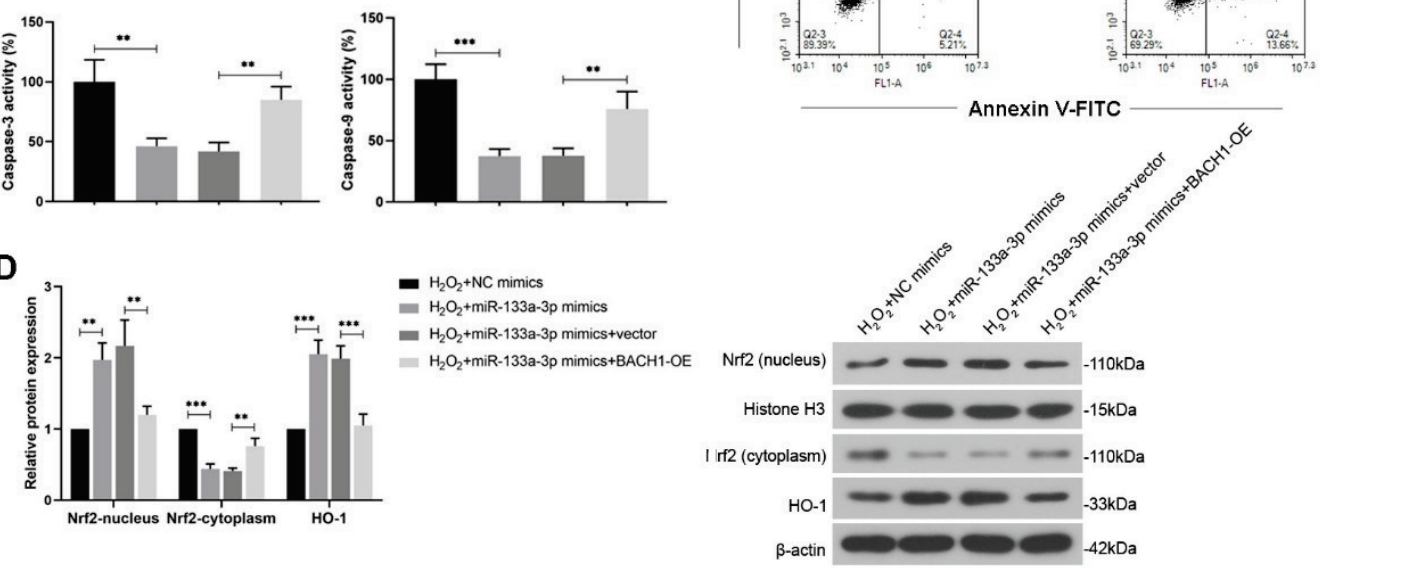

Fig. 5. MiR-133a-3p regulates $\mathrm{H}_{2} \mathrm{O}_{2}$-treated $\mathrm{HTR}-8 / \mathrm{SVneo}$ cell apoptosis and $\mathrm{Nrf2} / \mathrm{HO}-1$ signaling circuit through $\mathrm{BACH} 1$. (A) HTR-8/SVneo cells were transfected with the BACH1-overexpressed plasmid, and the transfection efficiency was detected using real-time PCR. (B) Flow cytometry was used to show relative apoptosis rate of $\mathrm{H}_{2} \mathrm{O}_{2}(250 \mu \mathrm{M})$-exposed trophoblast cells through PI/Annexin V-FITC double staining, after co-transfection of miR-133a-3p mimics and BACH1 overexpressed plasmid. (C) Activities of caspase-3 and caspase-9 were measured after co-transfection. (D) WB was performed to detect relative protein expression of nucleus $\mathrm{Nrf2}$, cytoplasmic $\mathrm{Nrf2}$ and $\mathrm{HO}-1$ in $\mathrm{H}_{2} \mathrm{O}_{2}$-treated trophoblast cells after co-transfection. $\mathrm{H}_{2} \mathrm{O}_{2}$, hydrogen peroxide; $\mathrm{NC}$, negative control; $\mathrm{BACH} 1, \mathrm{BTB}$ and $\mathrm{CNC}$ homology 1; Nrf2, nuclear factor-erythroid 2-related factor2; HO-1, heme oxygenase-1. One-way ANOVA combined with the Turkey multiple comparison test was used for data analysis.

with known mitochondria apoptotic pathway (Straszewski-Chavez et al. 2005), miR-133a-3p upregulation led to attenuated pro-apoptotic protein Bax levels which reduced the release of cytochrome $\mathrm{C}$ from mitochondria to cytoplasm without triggering more activities of caspase-9 and also its downstream caspase-3, resulting in alleviated apoptosis under oxidative stress in trophoblast cells. Interestingly, it has been reported that miR-133a-3p could target antiapoptotic Bcl-xL and Mcl-1 directly in human osteosarcoma MG63 cells to promote cell apoptosis (Ji et al. 2013), which seemed to contradict our findings. And in esophageal cancers, miR-133a-3p was shown to target EGFR to promote cell apoptosis (Yang et al. 2017). Besides, it was also reported that miR-133a-3p induced apoptosis in gastric cancer cells through directly binding with IGF1R (Gong et al. 2015). Apart from cancers, miR-133a-3p was shown to inhibit hypoxia- and $\mathrm{I} / \mathrm{R}$ injury-induced apoptosis in cardiomyocytes through targeting TAGLN2 and DAPK2 respectively (Li et al. 2015a, Li et al. 2015b). It seems that miR-133a-3p could act as a tumor suppressor in various cancers, but may also alleviate stress-induced apoptosis in other cell types, at least in cardiomyocytes and trophoblast cells from present study. MiR-133a-3p binds to other genes through multiple binding sites complementary to its seed sequence, which allows it to negatively regulate correlated genes and trigger off different signaling pathways in different cell types to respond to distinct stresses or disorders.

On the basis of the several published targets of miR-133a-3p, here, we studied another binding effect of miR-133a-3p on BACH1 which was regarded as a transcriptional repressor of Nrf2 to competitively inhibit its interactions with antioxidant response element (ARE) in the nucleus. In addition, in retinal ganglion cells, $\mathrm{H}_{2} \mathrm{O}_{2}$ treatment enhanced protein levels of $\mathrm{BACH} 1$, which was shown to negatively regulate downstream Nrf2 signaling to respond to oxidative stress (Jyrkkänen et al. 2011). Once cells were exposed to oxidative stress, free 
Nrf2 mainly dissociated from the Nrf2-Keap1 complex in the cytoplasm would translocate into the nucleus and bind to ARE to activate it, thereby regulating the activation of a range of antioxidant genes, including $H M O X 1$ encoding HO-1 (Giudice et al. 2010, Jyrkkänen et al. 2011). From further WB analysis in present study, $\mathrm{H}_{2} \mathrm{O}_{2}$-treated trophoblast cells with miR-133a-3p overexpression reduced cytoplasm Nrf2 levels but $\mathrm{Nrf} 2$ in the nucleus was enhanced with elevated HO-1 protein expression to protect cells from the oxidative stress through downregulating BACH1. Moreover, further BACH1 overexpression also reversed the effects of miR-133a-3p mimics on the trophoblast cell apoptosis and Nrf2/HO-1 signaling under $\mathrm{H}_{2} \mathrm{O}_{2}$ treatment. Hence, a BACH1/Nrf2/HO-1 signaling pathway was found to be involved in the regulatory mechanisms of miR-133a-3p in the HTR-8/SVneo cells treated with $\mathrm{H}_{2} \mathrm{O}_{2}$ through directly binding effects on $\mathrm{BACH} 1$, which protected trophoblast cells against oxidative stress and undoubtedly oxidative stress-induced apoptosis.

In the initial pre-experiments, miR-133a-3p expression was reduced gradually over time in $\mathrm{H}_{2} \mathrm{O}_{2}$ incubated trophoblast cells, combined with increased BACH1 expression, so that longer exposure of $\mathrm{H}_{2} \mathrm{O}_{2}$ would decrease the miR-133a-3p levels which may induce less antioxidant gene activities and bring serious damages of cells from oxidative stress. Associated with the effects of miR-133a-3p overexpression under oxidative stress in the trophoblast cells, an exogenous regulation of miR-133a-3p might be useful to reverse the oxidative stress-induced damages of trophoblast cells.
However, more pathological effects of it in the trophoblast cells should be explored and verified in vivo, which need more time and investigation in the future. Nevertheless, our findings at least proved the effects of miR-133a-3p to relieve the oxidative stress-induced trophoblast cell apoptosis, which may be considered as a choice for the treatment of PE-related trophoblastic diseases.

In conclusion, it is found that miR-133a-3p alleviates the oxidative stress induced by $\mathrm{H}_{2} \mathrm{O}_{2}$ in the HTR-8/SVneo cells and also attenuates the oxidative stress-induced cell apoptosis in trophoblast cells through an intrinsic mitochondrial apoptosis pathway. Dual luciferase assay indicates that miR-133a-3p directly targets 3'UTR of BACH1 and regulates BACH1 expression negatively. Meanwhile, miR-133a-3p overexpression enhances Nrf2/HO-1 signaling activity in the HTR-8/SVneo cells under oxidative stress through BACH1. Therefore, miR-133a-3p could relieve the oxidative stress-induced apoptosis by targeting BACH1 via regulating $\mathrm{BACH} 1 / \mathrm{Nrf} 2 / \mathrm{HO}-1$ signaling pathway in the trophoblast cells, which provides a novel therapeutic perspective to target miR-133a-3p for the treatment of oxidative stress-induced trophoblast cell abnormality.

\section{Conflict of Interest}

There is no conflict of interest.

\section{Acknowledgements}

This study was supported by a grant from the Health Commission Project of Hebei Province (No. 20201059).

\section{References}

ACKERMAN WE, BUHIMSCHI IA, EIDEM HR, RINKER DC, ROKAS A, ROOD K, ZHAO G, SUMMERFIELD TL, LANDON MB, BUHIMSCHI CS: Comprehensive RNA profiling of villous trophoblast and decidua basalis in pregnancies complicated by preterm birth following intra-amniotic infection. Placenta 44: 23-33, 2016. https://doi.org/10.1016/j.placenta.2016.05.010

AL-JAMEIL N, AZIZ KHAN F, FAREED KHAN M, TABASSUM H: A brief overview of preeclampsia. J Clin Med Res 6: 1-7, 2014. https://doi.org/10.4021/jocmr1682w

GIUDICE A, ARRA C, TURCO MC: Review of molecular mechanisms involved in the activation of the Nrf2-ARE signaling pathway by chemopreventive agents. Methods Mol Biol 647: 37-74, 2010. https://doi.org/10.1007/978-1-60761-738-9 3

GONG Y, REN J, LIU K, TANG LM: Tumor suppressor role of miR-133a in gastric cancer by repressing IGF1R. World J Gastroenterol 21: 2949-2958, 2015. https://doi.org/10.3748/wjg.v21.i10.2949

GROTEGUT CA: Prevention of preeclampsia. J Clin Invest 126: 4396-4398, 2016. https://doi.org/10.1172/JCI91300

HROMADNIKOVA I, KOTLABOVA K, IVANKOVA K, VEDMETSKAYA Y, KROFTA L: Profiling of cardiovascular and cerebrovascular disease associated microRNA expression in umbilical cord blood in gestational hypertension, preeclampsia and fetal growth restriction. Int J Cardiol 249: 402-409, 2017. https://doi.org/10.1016/j.ijcard.2017.07.045 
JI F, ZHANG H, WANG Y, LI M, XU W, KANG Y, WANG Z, WANG Z, CHENG P, TONG D, LI C, TANG H: MicroRNA-133a, downregulated in osteosarcoma, suppresses proliferation and promotes apoptosis by targeting Bcl-xL and Mcl-1. Bone 56: 220-226, 2013. https://doi.org/10.1016/j.bone.2013.05.020

JYRKKÄNEN HK, KUOSMANEN S, HEINÄNIEMI M, LAITINEN H, KANSANEN E, MELLA-AHO E, LEINONEN H, YLÄ-HERTTUALA S, LEVONEN AL: Novel insights into the regulation of antioxidantresponse-element-mediated gene expression by electrophiles: induction of the transcriptional repressor BACH1 by Nrf2. Biochem J 440: 167-174, 2011. https://doi.org/10.1042/BJ20110526

KUMAR D, LOU H, SINGAL PK: Oxidative stress and apoptosis in heart dysfunction. Herz 27: 662-668, 2002. https://doi.org/10.1007/s00059-002-2430-3

LI AY, YANG Q, YANG K: miR-133a mediates the hypoxia-induced apoptosis by inhibiting TAGLN2 expression in cardiac myocytes. Mol Cell Biochem 400: 173-181, 2015a. https://doi.org/10.1007/s11010-014-2273-2

LI P, NIJHAWAN D, BUDIHARDJO I, SRINIVASULA SM, AHMAD M, ALNEMRI ES, WANG X: Cytochrome c and dATP-dependent formation of Apaf-1/caspase-9 complex initiates an apoptotic protease cascade. Cell 91: 479-489, 1997. https://doi.org/10.1016/S0092-8674(00)80434-1

LI S, XIAO FY, SHAN PR, SU L, CHEN DL, DING JY, WANG ZQ: Overexpression of microRNA-133a inhibits ischemia-reperfusion-induced cardiomyocyte apoptosis by targeting DAPK2. J Hum Genet 60: 709-716, 2015b. https://doi.org/10.1038/jhg.2015.96

LV Y, LU C, JI X, MIAO Z, LONG W, DING H, LV M: Roles of microRNAs in preeclampsia. J Cell Physiol 234: 1052-1061, 2019. https://doi.org/10.1002/jcp.27291

MAJALI-MARTINEZ A, BARTH S, LANG U, DESOYE G, CERVAR-ZIVKOVIC M: Temporal changes of the endothelin system in human cytotrophoblasts during the first trimester of pregnancy. Physiol Res 67 (Suppl 1): S247-S255, 2018. https://doi.org/10.33549/physiolres.933828

MOL BWJ, ROBERTS CT, THANGARATINAM S, MAGEE LA, DE GROOT CJM, HOFMEYR GJ: Pre-eclampsia. Lancet 387: 999-1011, 2016. https://doi.org/10.1016/S0140-6736(15)00070-7

PU M, CHEN J, TAO Z, MIAO L, QI X, WANG Y, REN J: Regulatory network of miRNA on its target: coordination between transcriptional and post-transcriptional regulation of gene expression. Cell Mol Life Sci 76: 441-451, 2019. https://doi.org/10.1007/s00018-018-2940-7

REN L, WANG Q, CHEN Y, MA Y, WANG D: Involvement of microRNA-133a in the protective effect of hydrogen sulfide against ischemia/reperfusion-induced endoplasmic reticulum stress and cardiomyocyte apoptosis. Pharmacology 103: 1-9, 2019. https://doi.org/10.1159/000492969

SIBAI BM, STELLA CL: Diagnosis and management of atypical preeclampsia-eclampsia. Am J Obstet Gynecol 200 : 481.e481-487, 2009. https://doi.org/10.1016/j.ajog.2008.07.048

SONG T, YAO Y, WANG T, HUANG H, XIA H: Tanshinone IIA ameliorates apoptosis of myocardiocytes by up-regulation of miR-133 and suppression of caspase-9. Eur J Pharmacol 815: 343-350, 2017. https://doi.org/10.1016/j.ejphar.2017.08.041

STRASZEWSKI-CHAVEZ SL, ABRAHAMS VM, MOR G: The role of apoptosis in the regulation of trophoblast survival and differentiation during pregnancy. Endocr Rev 26: 877-897, 2005. https://doi.org/10.1210/er.2005$\underline{0003}$

UCHIDA Y, CHIYOMARU T, ENOKIDA H, KAWAKAMI K, TATARANO S, KAWAHARA K, NISHIYAMA K, SEKI N, NAKAGAWA M: MiR-133a induces apoptosis through direct regulation of GSTP1 in bladder cancer cell lines. Urol Oncol 31: 115-123, 2013. https://doi.org/10.1016/j.urolonc.2010.09.017

XU C, HU Y, HOU L, JU J, LI X, DU N, GUAN X, LIU Z, ZHANG T, QIN W, SHEN N, BILAL MU, LU Y, ZHANG Y, SHAN H: $\beta$-Blocker carvedilol protects cardiomyocytes against oxidative stress-induced apoptosis by up-regulating miR-133 expression. J Mol Cell Cardiol 75: 111-121, 2014. https://doi.org/10.1016/j.yjmcc.2014.07.009

YANG H, HE X, WANG C, ZHANG L, YU J, WANG K: Knockdown of TUG 1 suppresses hypoxia-induced apoptosis of cardiomyocytes by up-regulating miR-133a. Arch Biochem Biophys 681: 108262, 2020. https://doi.org/10.1016/j.abb.2020.108262 
YANG QS, JIANG LP, HE CY, TONG YN, LIU YY: Up-regulation of microRNA-133a inhibits the MEK/ERK signaling pathway to promote cell apoptosis and enhance radio-sensitivity by targeting EGFR in esophageal cancer in vivo and in vitro. J Cell Biochem 118: 2625-2634, 2017. https://doi.org/10.1002/jcb.25829

YIN Y, DU L, LI X, ZHANG X, GAO Y: miR-133a-3p suppresses cell proliferation, migration, and invasion and promotes apoptosis in esophageal squamous cell carcinoma. J Cell Physiol 234: 12757-12770, 2019. https://doi.org/10.1002/jcp.27896

YU L, LI D, LIAO QP, YANG HX, CAO B, FU G, YE G, BAI Y, WANG H, CUI N, LIU M, LI YX, LI J, PENG C, WANG YL: High levels of activin A detected in preeclamptic placenta induce trophoblast cell apoptosis by promoting nodal signaling. J Clin Endocrinol Metab 97: E1370-E1379, 2012. https://doi.org/10.1210/jc.2011-2729 